\section{Within the global circular economy: A special case of Turkey towards energy transition}

Selma Erat, Vocational School of Technical Sciences, Department of Medical Services and Techniques, Program of Opticianry, Mersin University, Mersin 33340, Turkey; Advanced Technology Education, Research and Application Center, Mersin University, Mersin 33340, Turkey

Azime Telli, Faculty of Economics and Administrative, Department of International Relations, Mersin University, Mersin 33340, Turkey Address all correspondence to Selma Erat at selma.erat@mersin.edu.tr (Received 8 June 2020; accepted 21 July 2020)

\title{
ABSTRACT
}

\section{Circular energy transformation of Turkey is essential to strengthen the national energy security. Turkey will benefit from moving towards a circular economy.}

Circular economy (CE) has gained much attention due to global warming and climate change which are the most serious issues faced in the world. The United Nations has been struggling with the issues regarding sustainable development by releasing some programs and legislations, which are mostly supported by the EU. The EU's CE including both economy and energy within the scope of low-carbon world is binding for Turkey's energy transition. Among renewables, solar energy preserved the leading capacity expansion with an increase of $98 \mathrm{GW}$ in 2019 in the world. Solar photovoltaic (PV) has become a mainstream energy source among renewables. Since the PV installation has been growing all around the world, several countries especially China, Germany, and the UK pay special attention to a sustainable PV waste management concept. We present the special case of Turkey within the global CE along with the current status of renewable energy in the global energy transformation. Turkey's energy outlook and the EU's targets are reviewed, and the significant role of solar energy in the CE transition process of Turkey has been revealed. We suggested adding a vision of "More Circular" to her new energy policy "More Domestic, More Renewable."

Key words: economics; energy generation; environmentally protective; photovoltaic; recycling

\section{Introduction}

The significance of energy to social and economic well-being has been increasing all around the world. Most of the energy demand is supplied by using fossil fuels, which are dominant contributors to greenhouse gas (GHG) emissions resulting in global warming and further climate change. The circular economy (CE) is defined as a systems-level approach to economic

\section{DISCUSSION POINTS}

- Global total solar energy capacity is top one among the renewables. The role of solar energy in the energy mix of Turkey is also getting more important. Do the present legislations and policy meet the requirement of circular economy of Turkey?

- The solar PV waste management of Turkey should be revised regarding the classification. Is the transition needed from "general waste" to "electronic waste" in accordance the EU's legislations? development designed to benefit businesses, society, and the environment. ${ }^{1}$ To tackle the climate crisis, the CE offers an approach that is not only powered by renewable energy, but also transforms the way products are designed and used. In other words, the main aim of the CE is to scale up low-carbon and efficiency solutions that will fulfill the Paris Agreement and the Sustainable Development Goals (SDGs). Struggling climate change and energy transformation are main challenges for a sustainable future. Thus, the policy makers take into accounts both ambitious plans about climate and enable business-led solutions in order to spread out and accelerate the implementation of the Paris Agreement. ${ }^{2}$

The environmental Kuznets curve (EKC) has been named for Kuznets $^{3}$ who hypothesized income (GDP) inequality first rises and then falls as economic development proceeds. ${ }^{4}$ The concept of EKC was mentioned for the first time, in the early $1990 \mathrm{~s}$, and it was popularized by the World Bank's World Development Report $1992 .{ }^{5}$ Stern $^{4}$ reported the development of the EKC concept in chronological order along with the theory 
behind the EKC, the econometric methods used in the EKC studies. The standard EKC regression model is given as following:

$\ln (E / P)_{i t}=\alpha_{i}+\gamma_{t}+\beta_{1} \ln (\mathrm{GDP} / P)_{i t}+\beta_{2}(\ln (\mathrm{GDP} / P))_{i t}^{2}+\varepsilon_{i t}$

where $E$ is emissions, $P$ is population, and $\ln$ indicates natural logarithms. The first two terms on the right-hand side are intercept parameters which vary across countries or regions $i$ and years $t$ as given by Stern. ${ }^{4}$ It has been discussed that the recent developments that have change the picture of standard EKC and the many studies are ongoing about that.

The CE concept that has gained much attention recently has been raised for the first time by Pearce and Turner. ${ }^{6}$ The concept presented the interlinkages between the environment and economic activities. There are several definitions about CE presented. ${ }^{7}$ Among these definitions, the CE is defined by European Institutions as an economy "where the value of products, materials and resources is maintained in the economy for as long as possible, and the generation of waste minimized." It is also worth to spread out the CE principles. For this, the governments, academia, and nongovernmental organizations, such as Ellen MacArthur Foundation, are responsible. Ellen MacArthur Foundation defined the $\mathrm{CE}$ as "an industrial system that is restorative or regenerative by intention and design. It replaces the "end-of-life" concept with restoration, shifts towards the use of renewable energy, eliminates the use of toxic chemicals, which impair reuse, and aims for the elimination of waste through the superior design of materials, products, systems, and, within this, business models." 8

It is obvious that moving from linear economy to CE can provide benefits such as reducing environmental pressures, improving the security of the supply of raw materials, increasing competitiveness, stimulating innovation, boosting economic growth, and creating jobs. Consequently, the CE is also helpful for strengthen national security due to the importance of sustainable energy supply. Thus, several governments including China, Japan, Canada, as well as the EU' members Germany, UK, The Netherlands, Sweden, and Finland promoted the CE concept. ${ }^{7,9}$

For the first time, in 1996, Germany started to the implementation of a model regarding the CE. The model only included recycle and waste management. Later, Japan developed a comprehensive legal framework for moving towards a recycling-based society. On the other hand, in 2008, China, as the first country in the world, adopted a law "Circular Economy Promotion Law." The 3R principles "Reduce, Reuse, and Recycle" mainly used by China, whereas $4 \mathrm{R}$ principles "Reduce, Reuse, Recycle and Recover" used by the EU. ${ }^{10,11}$ Concerning to the $\mathrm{CE}$, the EU underlines that the role of energy particularly renewables is important. One of the main goal of the EU is to increase the share of electricity generated from renewables to $20 \%$ by 2030 .

Several countries encourage the development of renewable resources in order to supply a secure, affordable, environment friendly and sustainable source of energy. ${ }^{11}$ Among the energy mix, solar energy is expected to be one of the main green energy sources in the future. Within the solar energy, the solar photovoltaic (PV)-based system is one of the fastest growing clean energy technology, because the costs decrease significantly and technology developments increase. ${ }^{12}$ According to the IEA report, the total cumulative installed capacity of PV was $627 \mathrm{GW}$ at the end of $2019 .{ }^{13}$

The solar PV technology, as well as the other clean sources, ages and degrades with time. The silicone-based PV modules have a life time of around $20-25$ years. It is necessary to take care of the PV waste at the end of the life time. Since the PV installation has been growing all around the world, a special attention of industries, policy maker, and stakeholders is needed for a sustainable PV waste management concept. ${ }^{12}$ There are lots of studies about the CE concept. Recently, the topic of renewable energy impact among the CE studies comes to front. Solar energy along with CE are mainly studied in Asia (China, Australia, and Japan), and then the EU (UK, The Netherlands, and Italy). ${ }^{7}$

The dynamic interaction between hydroelectricity energy, renewable energy consumption, and nonrenewable energy consumption on economic growth in the E7 countries, known as emerging among the fastest growing economies in the world, over annual time frequency data from 1990 to 2018 was investigated by using Kao co-integration technique. These seven countries (China, Turkey, Russia, India, Indonesia, Brazil, and Mexico) are known as the fastest growing energy-dependent countries. As a result of the investigation, a one-way causality relationship was observed between economic growth and renewable energy, nonrenewable energy, and pollutant emission. ${ }^{14}$ The 2009 Electricity Market and Security of Supply strategy of Turkey and the benefits of renewable energy technologies were examined from the point of the view of RE policy including legal regulations. ${ }^{15}$ As a result of the survey on Turkish citizens' energy preferences, it was indicated that a vast majority of the citizens were against the establishment of nuclear power plant and preferred renewable energy sources thanks to their awareness of global warming and climate change. ${ }^{16}$ It was reported that the solar PV electricity emerges as the largest contributor to cover the growing energy demand of Turkey and supply about $43.2 \%$ of total demand by $2050 .{ }^{17}$

However, there are few studies about the importance of solar energy for the CE of Turkey. The Influence of the EU Circular Economy Action Plan on Turkey's Energy Policy and Investments in Renewables were presented. ${ }^{18}$ The environmental benefits and economic recoveries of recycling PV module in Turkey were studied including technical aspects of engineering. ${ }^{19}$ The lack of the literature concerning to CE policy and implementation including renewables, particularly solar energy of Turkey that is a member of Organization for Economic Co-operation and Development (OECD) and a candidate of the EU, encourages us to work on this topic. The project of Sunrise was selected by the European Commission at the beginning of $2019^{20}$ and supported by Horizon 2020. Mersin University in Turkey is one of the supporters for Sunrise project 
with the title of "Solar Energy for a Circular Economy." This is also our motivation to research about the Turkey case.

We present the current status of renewable energy in the global energy transformation and the energy outlook and the special position of Turkey in the OECD, and then the CE targets of the EU which are binding for Turkey. The process of Turkey's CE transition is explained along with the project of Zero Waste. Furthermore, we present the role of solar energy and recycling PV module on the path of CE. The CE developments in Turkey is discussed, and some policy suggestions are presented in conclusion for future improvement.

\section{The current status of renewable energy in the global energy transformation}

One of the most serious concern of the 21 st century is global warming that results in climate change. The energy transformation swiftly reduces the GHG emissions that cause global warming and climate change. As aforementioned above, The Paris Agreement releases a target to limit the increase of global temperature to "well below" $2{ }^{\circ} \mathrm{C}$, and ideally to $1.5{ }^{\circ} \mathrm{C}$, compared with pre-industrial levels, by this century. In the global energy landscape, the energy transformation from fossil-based to renewable-based energy is essential to achieve the target. The energy transformation can support wide socio-economic development with help of comprehensive policies to encourage the societies for decarbonization.

According to the latest report of International Renewable Agency $^{21}$ (IRENA), the COVID-19 pandemic, which has caused to crises of health, humanitarian, social, and economic, could either widen the gap between the aspiration and the reality in tackling climate change or accelerate the decarbonization of societies. In order to reduce the GHG emissions, most of the countries increase the investments of renewable energy sources. However, still much efforts have to be put on to reach zero-level emissions. Figure 1 shows the outlook of energy-related $\mathrm{CO}_{2}$ emissions, energy demand, and fossil fuel.

Renewable energy has been established globally as a mainstream source of electricity generation for several years. The global renewable energy generation capacity increased by 176 GW in 2019 and reached up to $2.537 \mathrm{GW}$ at the end of 2019. ${ }^{22}$ Among the renewables, solar energy preserved the leading capacity expansion, with an increase of $98 \mathrm{GW}$ followed by wind energy with $59 \mathrm{GW}$ in 2019. The growth of renewable power capacity between 2015 and 2019 is shown in Fig. 2. In many electricity markets, the technology of solar PV and wind power are the cheapest and the installations of them are increasing. It was reported that most renewable power sources would be fully cost competitive within the next decade. ${ }^{21}$

PV has a significant role upon an energy transition process. The annual installations of renewable energy depending on the years are presented in Fig. 3 .

It is observed that the PV technology has reached an everincreasing market growth thanks to technology and cost reduction. Consequently, the PV technology has become a mainstream energy source upon the energy transition. ${ }^{13}$

\section{Turkey's energy outlook as a developing country}

Turkey has a population of $\sim 83$ million as of the beginning of 2020 which was 79.81 million in 2016 and 56.47 million in

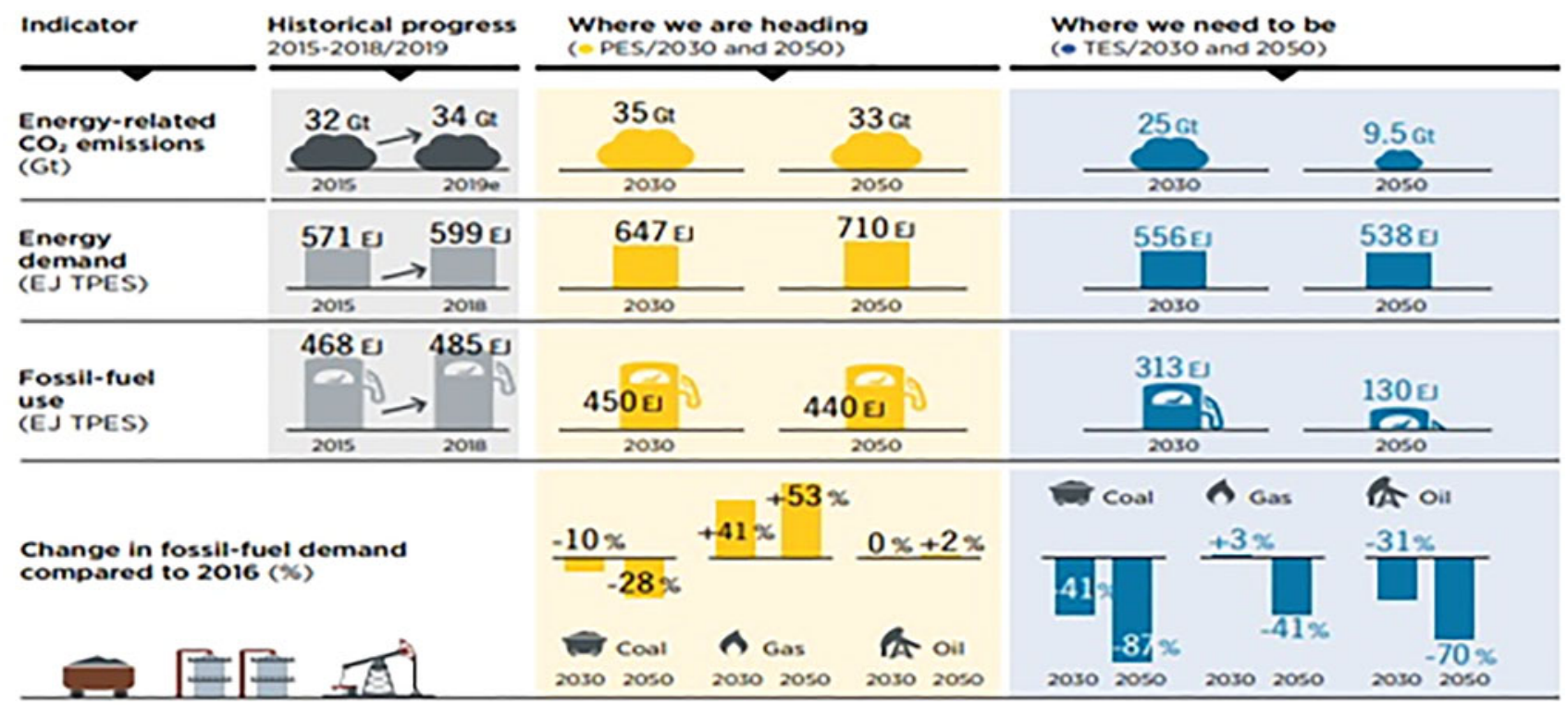

Note: TPES = total primary eneroy supply. e = estimate; Gt = gioatonnes; $\mathrm{E} J$ = exajoules.

Figure 1. The changing nature of energy and fossil fuel use ${ }^{21}$ (Reprinted with permission, (C IRENA). 


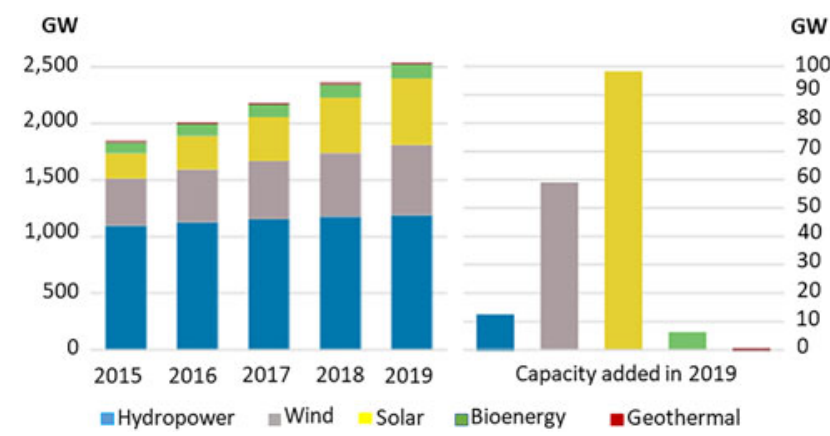

Figure 2. The growth of renewable power capacity (2015-2019) ${ }^{21}$ (Reprinted with permission, (C) IRENA).

$1990 .^{23}$ The population of Turkey is expected to increase up to 88.84 million in 2025 and further to 104.75 million in 2050. A decrease was observed in the rural population, while the urban population has been increasing since $1990 .{ }^{23}$ In $2019,92.8 \%$ of the population lived in cities and $7.2 \%$ lived in rural areas. ${ }^{23}$ The growing population, especially in urban areas, has a significant impact on increasing the demand of housing, transport, and energy. Consequently, the GHG emissions are expected to increase depending on the growing population. ${ }^{23}$ In 2018 , the total primary energy supply was 146 Mtoe. Besides, the total energy consumption accounted for $30.49 \%$ natural gas, $30.47 \%$ oil, and $17.28 \%$ coal in 2018 .

The Ministry of Energy and Natural Resources (MENR) of Turkey informed that the electric energy capacity reached $88,550 \mathrm{MW}$ at the end of 2018, generating 300 billion $\mathrm{kWh}$ of electricity. The renewable energy has the biggest share of the installed capacity $(47.73 \%)$ followed by natural gas $(24.26 \%)$ with respect to the data of Turkish Electricity Transmission Corporation. ${ }^{24}$ The share of renewable energy sources in the total capacity of Turkey was $42 \mathrm{GW}$ in 2018. Concerning to renewable energy, Turkey aims to add the

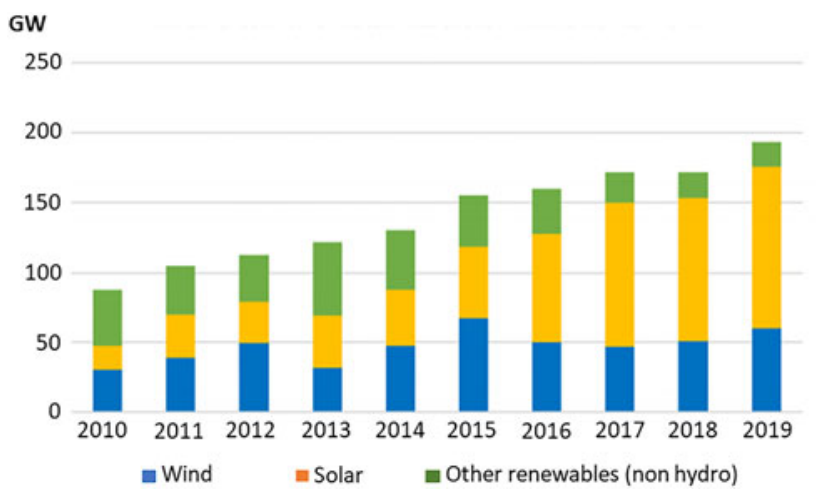

Figure 3. The evolution of renewable energy annual installations ${ }^{13}$ (Reprinted with permission, IEA, all rights reserved). capacity of 20,5, and $1 \mathrm{GW}$ for wind, solar, and geothermal by 2023 , respectively. According to the International Energy Agency (IEA), ${ }^{25}$ the installed renewable capacity of Turkey is expected to increase by $50 \%$ reach to $\sim 63 \mathrm{GW}$ from 2019 to 2024. One of the 2023 targets of Turkey is to generate $30 \%$ of total electric consumption from renewable sources in 2023.

Turkey decided to use nuclear energy in her energy mix, although it is not a renewable source. The construction of the nuclear power plant, which is the first nuclear power plant of Turkey, Akkuyu Nuclear Power Plant (Akkuyu NPP) in Akkuyu/Mersin, was started in 2010 by Russia. Akkuyu NPP has four units, $4800 \mathrm{MW}$ total capacity, and the first unit is expected to operate by $2023 .^{26}$ Furthermore, Turkey plans to establish second NPP in Sinop, Black Sea region and third NNP in the Thrace site of Turkey.

\section{Turkey's "special" position in the OECD}

Turkey is a developing country with a middle income whereas she is a member of the OECD. For this reason, Turkey has a "special" position among the OECD members. Turkey is one of the most growing GHG emissions among the OECD members. ${ }^{27}$ The emissions are expected to increase more than twice between 2015 and 2030 in Turkey. Although renewable energy development has been accelerated and energy efficiency was increased, the decline in emissions was less than in other members. Turkey signed the Paris Agreement in 2016. However, she has not ratified the agreement. According to the OECD,${ }^{27}$ Turkey needs a long-term, low-emission, and robust development strategy that will integrate climate and energy targets. Turkey, with her strong economic growth and increasing population, has the highest emission growth rate among the OECD countries for the last 10 years. ${ }^{27}$ Turkey is the only country within the OECD members who did not submit the 2020 targets concerning to reduction of GHG emissions to the OECD. On the other hand, Turkey declared her intention to decrease a GHG emission level at a rate of $21 \%$ from business as usual by 2030 with her long-term energy strategy for Intended Nationally Determined Contribution (INDC) to the United Nations Framework on Climate Change Convention (UNFCCG). ${ }^{28}$

Turkey's GHG emissions are a major part of energy usage similar to other OECD members. Therefore, it is important to ensure the strong policies that will lead the transition to a lowcarbon economy. As it was mentioned above, the energy demand of Turkey has been increasing. The energy supply mainly depends on imports and fossil fuels. It was reported that the only one-fourth of the energy supply could meet from domestic resources. ${ }^{27}$ Turkey has almost reached the targets of renewable energy set for 2023 in 2019 thanks to the feed-in tariff (FiT). To achieve this success, Turkey released her Renewable National Action Plan (NREAP) which was prepared according to the EU's targets in $2014 .^{29}$ The CE targets of the EU is important for Turkey. Thus, the targets are presented in the following section detail. 


\section{The CE targets of the European Union}

The CE targets of the EU are binding for Turkey because of her on-going processes of full membership. The CE that is based on sharing, leasing, reuse, repair, refurbishment, and recycling has been receiving much attention instead of "take-make-consume-throw away" pattern of the linear economy. It is obvious that the $\mathrm{CE}$ implies reducing waste to a minimum and further to zero level. In addition, it has advantages for both environmental and social conditions. From the point of the view of economic benefits, it could generate a net economic benefit of $€ 1.8$ trillion by 2030 . $^{30}$

It was mentioned that the EU's economy was mostly linear, with only $12 \%$ of materials recycled and brought back into the economy. ${ }^{31}$ The CE transformation could give opportunities to the EU to reduce the pressures on the environment; to enhance security of supply of raw materials; and to increase competitiveness, innovation, growth, and jobs. ${ }^{30}$

After the Global financial crisis in 2008, especially the resource productivity/efficiency (doing more with less) within the "green growth" received much more attention. Thus, a vision of a Resource Efficient Europe, as an important part of the "Europe 2020 Strategy," was built up. ${ }^{32}$ Since the beginning of 2000s, many environmental legislations and programs have been evolved due to the concerns grown in the EU. The latest one is the EU CE which is binding the economy and energy within the scope of low-carbon world. The EC adopted an ambitious Circular Economy Package in 2015, which enhances the strategy to protect environment and includes measures that will help stimulate Europe's transition towards a CE, boost global competitiveness, foster sustainable economic growth, and generate new jobs. The EU Action Plan for the CE has a concrete and ambitious program including measures from production and consumption to waste management and the market for secondary raw materials and a revised legislative proposal on waste. $^{33}$ The importance of energy and renewables to improve the efficiency and environmental performance of energy-related products are underlined in the Package. ${ }^{8}$ Energy while defining $\mathrm{CE}$ was mentioned to consume and return back to the environment as waste by Charonis. ${ }^{34}$

The new Circular Economy Action Plan ${ }^{33}$ adopted in 2020 presents measures to:

- Make sustainable products the norm in the EU;

- Empower consumers and public buyers;

- Focus on the sectors that use most resources and where the potential for circularity is high such as electronics and ICT; batteries and vehicles; packaging; plastics; textiles; construction and buildings; food; water and nutrients;

- Ensure less waste;

- Make circularity work for people, regions, and cities;

- Lead global efforts on CE.

To reach the EU's clean energy targets, solar power has a significant role. In 2019, a 104\% increase over the $8.2 \mathrm{GW}$ added the year before and the installed capacity reached to $16.7 \mathrm{GW} .^{35}$
The EU's target is to reach $20 \%$ share of energy from renewable sources and to use $10 \%$ of this value in the transport sector by 2020 in respect to the Europe 2020 Strategy.

The PV panels were classified as "general waste" by most of the countries. However, for the first time, the EU adopted $\mathrm{PV}$-specific waste regulations including PV-specific collection, recovery, and recycling targets. All of the panel producers for the EU market are required to finance the costs of collecting and recycling end-of-life PV panels according to the EU's directive. $^{36}$

\section{The process of Turkey's CE transition}

The CE is a new production model based on sustainability and innovation, where every waste generated in a production system is recycled, so raw material costs are minimized, resource efficiency and environmental benefits are kept to a maximum.

Turkey has put her efforts for CE transition since the last decade. Turkey that follows the EU's legislations has much to do on the path of the transition. The role of the public is quite important as well as the government initiatives. Thus, nongovernmental organization contributions are also important to the increase of awareness of the public. Business Council for Sustainable Development Turkey (BCSD Turkey), as a leading platform in this sense, is working in line with the United Nations' SDGs.

The principle goals of the BCSD for widespread sustainability and CE development in Turkey are in following: ${ }^{37}$

1. Transition to low-carbon economy and efficiency

2. Sustainable agriculture and access to food

3. Sustainable industry and CE

4. Social inclusion

It was reported that Turkey could have an opportunity to receive 15-27 billion $\$$ (USD) of net value with the help of evolving the CE model. ${ }^{18}$ One of the essential principles of CE is recycling municipal waste. The Turkish government has taken important steps regarding the recycling. In 2017, the first lady of Turkey, Emine Erdogan launched a Zero Waste Project in collaboration with the Ministry of Environment and Urbanization in order to stop resources from ending in landfill and increase public awareness about waste management. The project is compulsory for all municipalities and public and private organizations to provide a certain amount of waste separation facilities per area. In 2018, the recycling rates of municipal solid waste already increased to $15 \%$ thanks to the project. The aim of the project is to increase the recycling rate of municipal solid waste to $35 \%$ by 2023 . The project also aims to reduce the usage of the plastic bags and almost $80 \%$ reduction was succeeded in $2018 .^{38}$

Turkey has launched her energy market reform for the transition to low-carbon economy and efficiency. ${ }^{39}$ Such reforms have attracted significant private investment. The total amount of investments for electricity generation from renewable energy has exceeded 4.3 billion $\$$ (USA) in the past 15 years. Among these investments, the solar energy has an important role. 
The role of solar energy in the CE transition process of Turkey

The energy demand of Turkey has been increasing quite fast compared with the OECD countries. Next, the demand is expected to be double according to IEA forecasts till 2030 . Turkey has set the formulation and implementation of new policies to commission domestic and renewable energy resources due to the fact that the high rate of energy imports dependency. ${ }^{40}$

The Government has promoted the motto of "More Domestic, More Renewable" and determined the following targets to strengthen renewables' position in for the energy action for the next decades. Regarding to the targets, the share of renewables has to be increased $30 \%$ of the present level by 2023. ${ }^{40}$ Turkey has a great renewable potential, and according to IEA' estimation, she may become the fifth biggest in Europe by renewable energy capacity by 2024 , and the 11 th in the world.

Among the renewable resources, the solar installed capacity, which is $5435 \mathrm{MW}$, will be increased up to $16,000 \mathrm{MW}$ by $2027 .{ }^{41}$ It was reported that the cost reduction had an important role on wide spreading of solar energy. The PV module prices dropped by $85 \%$ from 2010 to 2019 and further an additional drop of $71 \%$ is expected by $2050 .^{41}$

Turkey is the country to receive the most sunlight in Europe and she is one of the so-called sun-belt countries (66) (the zone receiving the highest amount of solar irradiation) identified by the European Photovoltaic Industry Association (EPIA). Such countries have huge PV solar potential not only to supply energy to their own region, but to export energy to other parts of the world. The sun-belt countries are expected to have 1.1 TW installed solar PV capacity by $2030 .{ }^{42}$ The sun-belt countries from low to high potentials are presented by the EPIA. ${ }^{43}$ Solar energy can compete with conventional energy sources without any grant thanks to the cost reduction. Consequently, solar energy investments in Turkey has been increasing significantly. For the first time in 2017, Turkey took a place as the fifth largest capacity in the list announced by the IEA. ${ }^{44}$ Top ten countries for PV installations in 2017 are given in Table 1.

The Mechanism for Supporting Renewable Energy Resources (YEKDEM) program, which started in 2011 and supported by the MENA, provided an attractive feed-in tariff scheme for renewable power projects. The YEKDEM program will be expired at the end of 2020 . Thus, in order to encourage the development and use of domestic manufacture of equipment required for large-scale renewable energy generation facilities, Turkey adopted the Regulation on Renewable Energy Resource Area scheme (YEKA) in 2016. ${ }^{45}$

\section{Turkey's PV capacity and recycling}

Solar energy has an important role upon the low-carbon energy transition due to the climate change problem. From the point of the view of solar energy market, the PV solar module installations are growing quite fast. The crystalline $\mathrm{Si}$
Table 1. The list of top ten countries for PV installations in $2017 .^{44}$

\begin{tabular}{l|c}
\hline \multicolumn{1}{l}{ Countries } & Capacity (GW) \\
\hline China & 53 \\
\hline USA & 10.6 \\
\hline India & 9.1 \\
\hline Japan & 7 \\
\hline Turkey & 2.6 \\
\hline Germany & 1.8 \\
\hline Australia & 1.25 \\
\hline Korea & 1.2 \\
\hline UK & 0.9 \\
\hline Brazil & 0.9 \\
\hline
\end{tabular}

module share is $\mathbf{8 5 - 9 0 \%}$ among the PV panel technologies. ${ }^{46}$ Each module has a lifetime which means increasing the installation of the modules increases the waste of modules expected to reach up to 5.5-6 million tons by 2050. For the CE model, the recycling of the PV modules is important. Consequently, methods for recycling PV modules have been developed worldwide in order to reduce the environmental impact of PV waste and to recover some of the value from old modules. ${ }^{46}$

Turkey as a sun-belt country is among the largest developing solar markets and she has a share of 6.5\% (91.26 GW in 2019) solar capacity within power generation capacity. Turkey's total solar energy installed capacity between 2014 and 2019 and the expected capacity depending on low and high scenarios are presented in Fig. 4.

The 169.7 MW capacity is supplied with the licensed PV projects under the support of the government. Besides, the unlicensed PV systems have $5,826 \mathrm{MW}$ in total solar capacity. ${ }^{48}$ The unlicensed PV systems are quite popular under $1 \mathrm{MW}$ capacity because of the advantage of the unlicensed (FiT) schemes. ${ }^{39}$ Turkey's PV capacity in total solar energy (20082018) is shown in Fig. 5.

Figure 6 shows the PV contribution, which is theoretically calculated to the electricity demand in several countries based on the PV capacity installed by the end of 2019 . Honduras having $14.8 \%$ is on top of the list. Turkey with a theoretical penetration level of $5.1 \%$ was higher than that of the EU level $(4.9 \%)$ and also the world level $(3.0 \%){ }^{13}$

It is estimated that Turkey's rooftop PV installation capacity is approximately $15 \mathrm{GW}$ more than twice that of Turkey's current installed solar power. ${ }^{49}$ Thanks to raising awareness of 


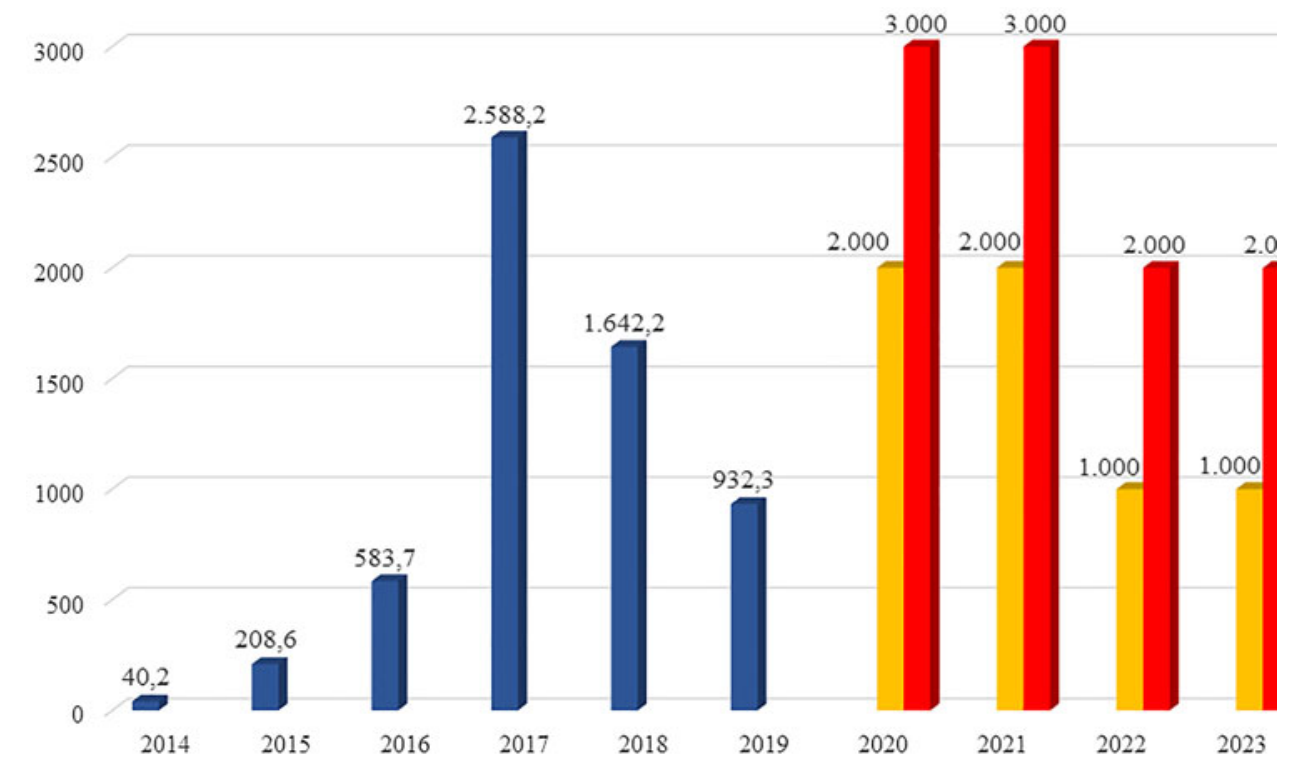

Figure 4. Turkey's current status of total solar energy capacity and expected values. ${ }^{47}$ (The values of 2018 and 2019 are inserted and the graph is updated; Reprinted with permission, Gunder.)

6

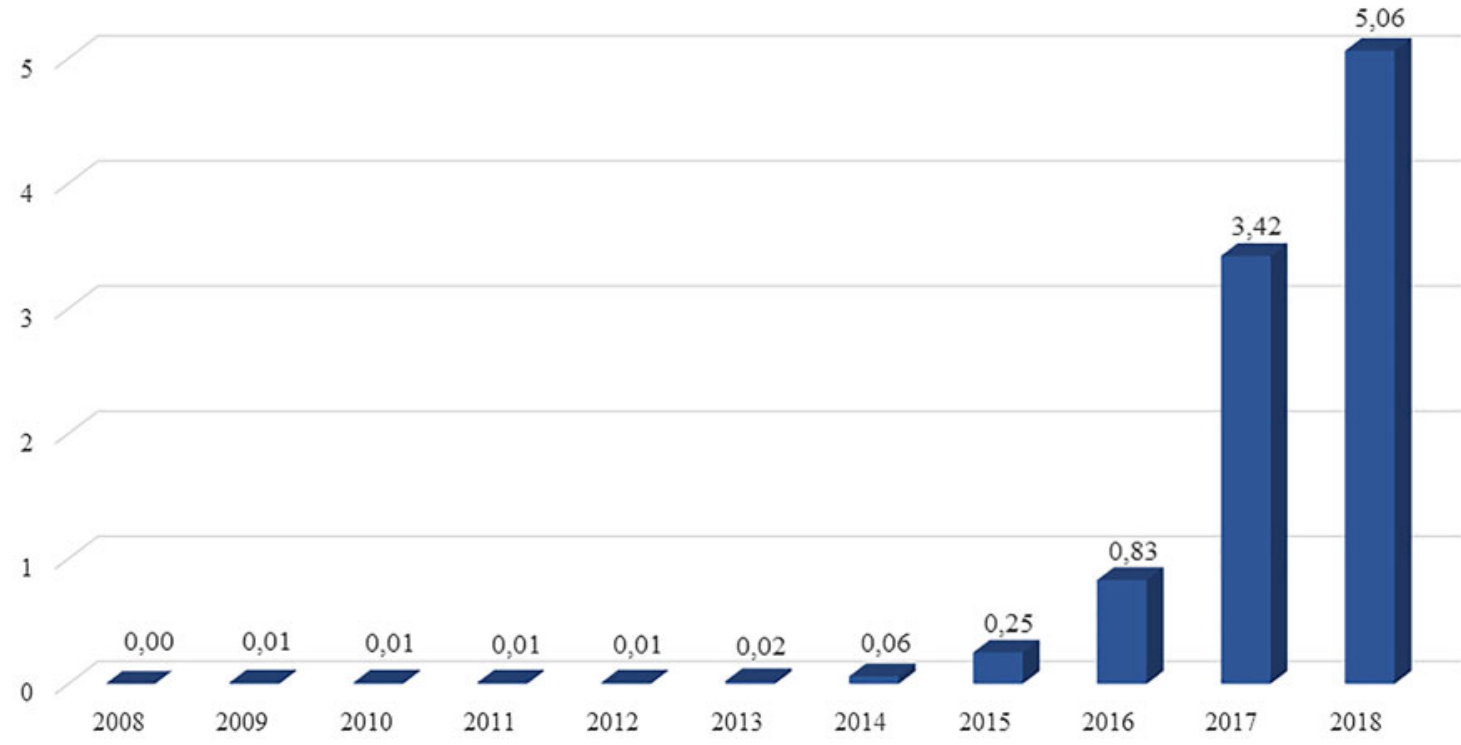

Figure 5. Turkey's PV capacity in total solar energy (GW) (2008-2018) ${ }^{13}$ (Reprinted with permission, IEA, all rights reserved).

Turkish society about green energy, the PV market has grown in all dimensions from production to installation. ${ }^{50}$ It is obvious that PV systems upon the operation phase (25-30 years) do not produce any GHG emissions. However, the impact of total environment must be taken into account throughout its entire lifecycle. It was mentioned that recycling the end-of-life PV modules could significantly reduce the energy consumption and carbon emission, and alleviate lifecycle resource depletion. ${ }^{51}$

Turkey's total module number was reported as 3.3 million in 2018 by Gönen and Kaplanoğlu. ${ }^{19}$ The $60-70 \%$ of these 


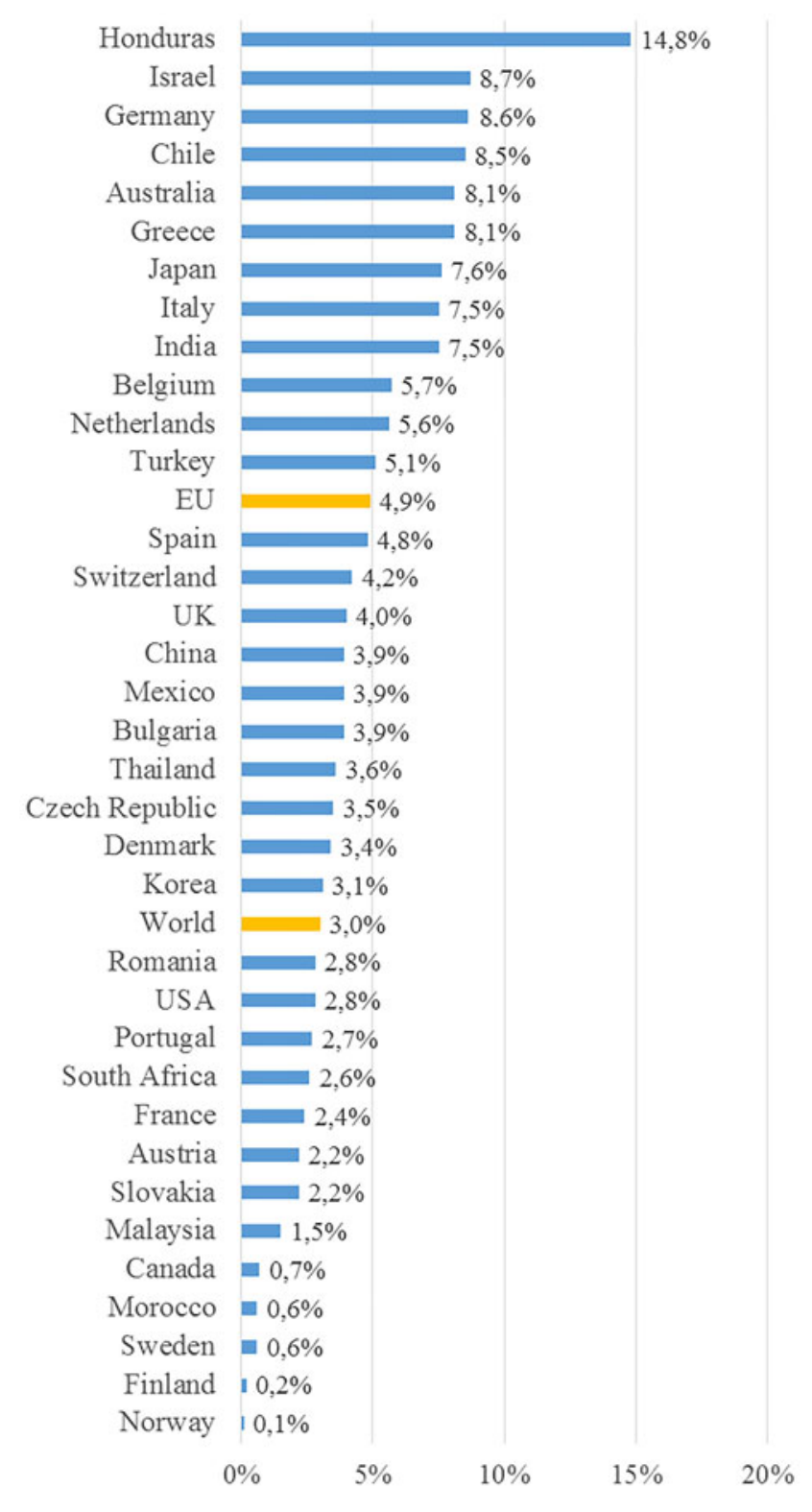

Figure 6. PV contribution theoretically calculated for several countries in $2019^{13}$ (Reprinted with permission, IEA, all rights reserved). The values in the figure are in percent $(\%)$ of electricity demand.

modules are assumed to be recycled, whereas $30-40 \%$ of the remaining modules are assumed nonrecycled or already they deinstalled before their end of life due to the lack of regulation related to the PV recycle. In this context, once the recycle ratio of PV modules in Turkey was selected as $65 \%$, the recycled metals' economic value would be approximately 30 million $\$$ (USD). ${ }^{19}$

The legislations concerning to PV waste were included in the Waste Electrical and Electronic Equipment Directive (WEEE Directive) of the EU in 2012. ${ }^{52}$ In 2015, Turkey adopted the WEEE, whereas the PV modules are not officially accepted as electronic waste. The current system in Turkey is still insufficient to meet the collection and treatment targets given in the WEEE Regulation. It is important to classify the PV modules as electronic waste and also define the criteria of the recycling process.

\section{Conclusion}

The CE policy has accelerated significantly since the last two decades all around the world. The CE policies started to be implied in the 2000s, whereas the concept of the CE has already been known since 1970s. Recently, the CE concept has been growing quite fast not only in developed countries but also in developing countries including Turkey. On the way of the CE, Turkey as a candidate country of the EU has drawn a road map in accordance with the EU's legislations. Such efforts of Turkey on this path are also helpful to meet the OECD's targets.

Turkey is conscious of the importance of CE and the need of energy transition. Thus, Turkey has increased the renewable investments since 2000s and reduced the import dependency. The growing rate of renewable energy investments in Turkey brings a new issue, which is "recycling." The Zero Waste Project of Turkey is helpful particularly for municipal waste recycling. However, Turkey has to define a comprehensive legal infrastructure regarding the recycling process of electronic waste including PV modules.

Turkey has a much higher solar energy potential than the UK and Germany, which are the leading countries in this field. The rate of the investments regarding PV power has been increasing in Turkey. The lifetime is expected to expire and makes encounter problems in 2040s. Within the green economy process, the recycling of these PV panels is quite important. To benefit from that (e.g., achieving a sufficient sustainable industry, economy, and clean environment), Turkey should increase the effort for $\mathrm{CE}$ and complete the legislations as soon as possible. For this, the EU countries that are already started to the CE, particularly Germany, may play a role model for Turkey.

Adding the priority of CE with "More Circular" vision into the policy of "More Domestic, More Renewable" will be helpful for economic development, supplying the grown energy demand, and reducing GHG emissions of Turkey.

\section{REFERENCES:}

1. Ellen MacArthur Foundation: Completing the Picture: How the Circular Economy Tackles Climate Change, 2019. Available at: www. ellenmacarthurfoundation.org/publications/completing-the-pictureclimate-change (accessed May 29, 2020).

2. World Business Council for Sustainable Development: Climate Action and Policy. Available at: https://www.wbcsd.org/Programs/Climate-andEnergy/Climate/Climate-Action-and-Policy (accessed May 28, 2020).

3. Kuznets S.: Economic growth and income inequality. Am. Econ. Rev. 49, 1-28 (1955).

4. Stern D.I.: The rise and fall of the environmental Kuznets Curve. World Dev. 32(8), 1419-1439, (2004).

5. The International Bank for Reconstruction and Development (IBRD): World Development Report 1992. Development and the Environment (Oxford University Press, 1992), New York. 
6. Pearce D.W. and Turner R.K.: Economics of Natural Resources and the Environment (John Hopkins University Press, 1990), Baltimore, MD.

7. Merli R., Preziosi M., and Acampora A.: How do scholars approach the circular economy? A systematic literature review. J. Clean. Prod. 178, 703 (2018).

8. Ellen MacArthur Foundation: Towards the Circular Economy: Opportunities for the Consumer Goods Sector, Vol. 2. (Hughes, 2013). Available at: Towards the Circular Economy: Opportunities for the Consumer Goods Sector (accessed May 27, 2020).

9. Su B., Heshmati A., Geng Y., and Yu X.: A review of the circular economy in China: Moving from rhetoric to implementation. Clean. Prod. 42, 215 (2013).

10. Kirchherr J., Reike D., and Hekkert M.: Conceptualizing the circular economy: An analysis of 114 definitions. Resourc. Conserv. Recycl. 127, 221 (2017).

11. Zhu Y. and Zhu D.J.: A revised circular economy model and its application based on objectivity- process-subjectivity analysis. Shanghai Environ. Sci. 26 (1), 14-18 (2007).

12. Sharma A., Pandeyb S., and Kolhea M.: Global review of policies and guidelines for recycling of solar PV modules. Int. J. Smart Grid. Clean Energy 8(5), 597-610, (2019).

13. IEA PVPS: 2019 Snapshot of the Global PV Market, 2020. Available at: https://iea-pvps.org/wp-content/uploads/2020/02/IEAPVPS_T1_35_Snapshot2019-Report.pdf (accessed May 15, 2020).

14. Gyamfi B.A., Bein M.A., and Bekun F.V.: Investigating the nexus between hydroelectricity energy, renewable energy, nonrenewable energy consumption on output: evidence from E7 countries. Environ. Sci. Pollut. Res 27, 25327-25339 (2020).

15. Tükenmez M. and Demireli E.: Renewable energy policy in Turkey with the new legal regulations. Renew. Energy 39(1), 1-9, (2012).

16. Ozcan M.: Factors influencing the electricity generation preferences of Turkish citizens: Citizens' attitudes and policy recommendations in the context of climate change and environmental impact. Renew. Energy 132, 381-393, (2019).

17. Kilickaplan A., Bogdanov D., Peker O., Caldera U., Aghahosseini A., and Breyer C.: An energy transition pathway for Turkey to achieve $100 \%$ renewable energy powered electricity, desalination and non-energetic industrial gas demand sectors by 2050. Solar Energy 158, 218-235 (2017).

18. Okay E.: Influence of the EU circular economy action plan on Turkey's energy policy and investments in renewables. In The Circular Economy and Its Implications on Sustainability and the Green Supply Chain, 119, Akkucuk U., ed. (IGI Global, USA, 2019).

19. Gönen Ç and Kaplanoğlu E.: Environmental and economic evaluation of solar power wastes recycling. Waste Manage. Res. 37(4), 412-418 (2019).

20. Abbott A.: Six teams vie for billion-euro funding. Nature 566, 164-165 (2019).

21. IRENA: Global Renewables Outlook: Energy Transformation 2050 (IRENA, 2020), Abu Dabi.

22. IRENA: Renewable Capacity Highlights, 2020. Available at: https://irena. org/-/media/Files/IRENA/Agency/Publication/2020/Mar/IRENA_RE_ Capacity_Highlights_2020.pdf?la=en\&hash=B6BDF8C3306D271327729 B9F9C9AF5F1274FE30B (accessed July 03, 2020).

23. Ministry of Environment and Urbanization: Turkey's Seventh National Notification (Ministry of Environment and Urbanization, 2018), Ankara, Turkey.

24. TEIAS: Electricity Transmission Sector Report of Turkey 2018, 2019. Available at: https://teias.gov.tr/tr-TR/sektor-raporlari (accessed December 15, 2019).

25. IEA: Country Profile: Turkey, 201. Available at: www.iea.org/countries/ turkey (accessed February 02, 2020).

26. Telli A.: Akkuyu nuclear power plant from the perspective of energy security: A solution or a deadlock? Caucasus Int. 6, 151-166 (2016).

27. OECD: Environmental Performance Reviews: Turkey 2019 (OECD, 2019), Paris, France.

28. Ministry of Foreign Affairs: Turkey's Energy Profile and Strategy, 2015. Available at: http://mfa.gov.tr/turkeys-energy-strategy.en.mfa (accessed January 27, 2020)
29. MENR: National Renewable Action Plan (MENR, 2014), Ankara, Turkey.

30. McKinsey Center for Business and Environment: Europe's Circular-Economy, 2015. Available at: www.mckinsey.com/ /media/ McKinsey/Business\%20Functions/Sustainability/Our\%20Insights/ Europes\%20circular\%20economy\%20opportunity/Europes\% 20circulareconomy\%20opportunity.ashx (accessed May 15, 2020).

31. Simon F.: EU Unveils Circular Economy Plan 2.0, Drawing Mixed Reactions, 2020. Available at: www.euractiv.com/section/circulareconomy/news/eu-unveils-circular-economy-plan-2-0-drawing-mixedreactions/ (accessed May 15, 2020).

32. European Academies Science Advisory Council: Circular Economy: A Commentary from the Perspectives of the Natural and Social Sciences, 2015. Available at: https://easac.eu/fileadmin/PDF_s/reports_statements/ EASAC_Circular_Economy_Web_revised.pdf (accessed May 15, 2020).

33. European Commission: Circular Economy Action Plan for a Cleaner and More Competitive Europe, 2020. Available at: https://ec.europa.eu/ environment/circular-economy/ (accessed May 14, 2020).

34. Charonis G.K.: Degrowth, Steady State Economics and the Circular Economy: Three Distinct Yet Increasingly Converging Alternative Discourses to Economic Growth for Achieving Environmental Sustainability and Social Equity, 2012. Available at: https://sustainabilityconference2012. weaconferences.net/papers/degrowth-steady-state-economics-and-thecircular-economy-three-distinct-yet-increasingly-converging-alternativediscourses-to-economic-growth-for-achieving-environmentalsustainability-and-social-eq/ (accessed July 02, 2020).

35. Solar Power Europe: EU Solar Boom: Over 100\% Solar Market Increase in 2019, 2019. Available at: https://www.solarpowereurope.org/eu-solarboom-over-100-solar-market-increase-in-2019/ (accessed May 31, 2020).

36. IRENA: End-of-Life Management: Photovoltaic Panels, 2016. Available at: www.irena.org/documentdownloads/publications/irena_ieapvps_end-oflife_solar_pv_panels_2016.pdf (accessed May 18, 2020).

37. BCSD: Sustainable Industry and Circular Economy, 2018. Available at: www.skdturkiye.org/en/surdurulebilir-sanayi-ve-dongusel-ekonomi (accessed May 18, 2020).

38. Daily Sabah: From Zero to the Future: National Recycling Movement Gathers Momentum, 2020. Available at: https://www.dailysabah.com/ turkey/2020/01/01/from-zero-to-the-future-national-recyclingmovement-gathers-momentum (accessed July 04, 2020)

39. World Bank Group: Turkey: Rooftop Solar Market Assessment Summary Note, 2018. Available at: http://documents.worldbank.org/curated/en/ 532211519629608085/pdf/TR-Rooftop-Solar-Output-P162236.pdf (accessed May 18, 2020).

40. Presidency of the Republic of Turkey Investment Office: Invest in Turkey: Why Invest in Turkey Energy Sector, 2020. Available at: https://invest.gov. tr/en/publications/Pages/default.aspx (accessed January 15, 2020).

41. Bloomberg New Energy Finance: Clean Energy Investment Exceeded $\$ 300$ Billion Once Again in 2018, 2019. Available at: https://about.bnef.com/ blog/clean-energy-investment-exceeded-300-billion-2018/ (accessed May 25, 2020).

42. Aura Solar: Solar-Photovoltaic Energy, 2020. Available at: http://www.aura solar.com.mx/eng/solar-photovoltaic-energy.html (accessed May 27, 2020).

43. EPIA: Unlocking the Sunbelt Potential of Photovoltaics (EPIA, 2010), Brussels.

44. IEA PVPS: 2017 Snapshot of the Global PV Market, 2018. Available at: https://iea-pvps.org/wp-content/uploads/2020/01/IEA-PVPS__A_Snapshot_of_Global_PV_-_1992-2017.pdf (accessed May 13, 2020).

45. Project Finance International: Breaking New Ground with YEKA, 2020. Available at: http://www.pfie.com/breaking-new-ground-with-yeka/ 21412936.fullarticle (accessed May 23, 2020).

46. Lunardi M.M., Alvarez-Gaitan J.P., Bilbao J.I., and Corkish R.: A review of recycling processes for photovoltaic modules. In Solar Panels and Photovoltaic Materials, Zaidi B., ed. (IntechOpen, 2018), doi.org/10.5772/ intechopen.74390.

47. International Solar Energy Society Turkey Section (GUNDER): The Roadmap of Solar Power, 2018. Available at: file://E:/CIRCULAR\% 20PHOTOVOLTAIC\%20ENERGEY\%20FOR\%20TURKEY/G\%C3\%BCne\% C5\%9Fin-Yol-Haritas\%C4\%B1-Rapor-2018.pdf (accessed June 01, 2020). 
48. Bellini E.: Turkish Solar Reaches 6 GW, 2020. Available at: https://www.pvmagazine.com/2020/01/20/turkish-solar-reaches-6-gw/ (accessed May 14, 2020).

49. Acar A., Sarı A.C., and Taranto Y.: Rooftop Solar Energy Potential of Buildings-Financing Models and Policies for the Realization of Rooftop Solar Energy Systems in Turkey. (SHURA, 2020), Istanbul, Turkey.

50. Onsomu O.N. and Yeşilata B. Virtual power plant application for rooftop photovoltaic systems. In 2019 3rd International Symposium on
Multidisciplinary Studies and Innovative Technologies (ISMSIT), Ankara, Turkey, 1-5, (2019) doi: 10.1109/ISMSIT.2019.8932895.

51. Deng R., Chang N.L., Ouyang Z., and Chong Z.M.: A techno-economic review of silicon photovoltaic module recycling. Renew. Sust. Energ. Rev. 109(C), 532-550 (2019).

52. PV Magazine: Solar Modules Now Officially Regarded as E-waste, 2012. Available at: www.pv-magazine.com/2012/01/30/solar-modules-nowofficially-regarded-as-e-waste_10005611/(accessed May 25, 2020). 